\title{
PERKEMBANGAN MORFOLOGI GRESIK KOTA BANDAR DENGAN PENDEKATAN ANALISA DIAKRONIK
}

\section{THE URBAN MORPHOLOGICAL DEVELOPMENT OF GRESIK KOTA BANDAR ON THE DIACHRONIC FRAMEWORK ANALYSIS}

\author{
Gratia Ananda Sinaga ${ }^{a}$, Karina Pradinie Tucunan ${ }^{\text {, }}$, Putu Rudy Satiawan ${ }^{c}$ dan Dian Rahmawati ${ }^{\text {d }}$ \\ aDepartemen Perencanaan Wilayah dan Kota; Institut Teknologi Sepuluh Nopember (ITS); Surabaya; gratiananda@gmail.com \\ bDepartemen Perencanaan Wilayah dan Kota; Institut Teknologi Sepuluh Nopember (ITS); Surabaya; kp.tucunan@gmail.com \\ 'Departemen Perencanaan Wilayah dan Kota; Institut Teknologi Sepuluh Nopember (ITS); Surabaya; puturudy@yahoo.com \\ dDepartemen Perencanaan Wilayah dan Kota; Institut Teknologi Sepuluh Nopember (ITS); Surabaya; dnrahmawati@gmail.com
}

Info Artikel:

- Artikel Masuk: 23 November 2020

- Artikel diterima: 5 Februari 2021

- Tersedia Online: 30 September 2021

\begin{abstract}
ABSTRAK
Kabupaten Gresik sebagai Bandar telah dikenal sejak Masa Kerajaan Majapahit karena lokasi yang strategis dan kegiatan perdagangan yang tinggi sehingga menjadikan Gresik sebagai Kota Bandar. Keberadaan Bandar Gresik menjadi salah satu alasan keberagaman sejarah dan budaya yang terdapat di dalamnya karena adanya akulturasi dari budaya pendatang yang ditimbulkan oleh Bandar itu sendiri. Bandar menjadi salah satu pencetus perkembangan masyarakat dan ekonomi yang semakin terlihat pada morfologi Kota Kabupaten Gresik. Adanya peninggalan Sejarah yang beragam, baik tangible maupun intangible menggambarkan peristiwa sejarah yang pernah terjadi di Kabupaten Gresik di masa lalu dan perkembangan kota yang terjadi hingga saat ini. Peristiwa sejarah Kabupaten Gresik ini kemudian dapat menjadi identitas dan kekhasan tersendiri untuk Kabupaten Gresik. Oleh karena itu perlu dilakukan studi mengenai perkembangan Gresik dengan tujuan untuk mengetahui perkembangan morfologi sebagai dasar penelitian-penelitian selanjutnya, yang termasuk di dalamnya pengembangan Kota Pusaka dan Pengembangan Berbasis Historical Urban Landscape. Penelitian ini menggunakan pendekatan analisa content analysis (CA) dan analisis Diankronik. Hasil penelitain ini ditemukan 5 tahapan periode utama yang terdiri dari Masa Kerajaan Majapahit, Masa Perkembangan Islam, Masa Kolonial, Masa Pendudukan Jepang, dan Masa Awal Kemerdekaan. Berdasarkan periode perkembangan tersebut kemudian dikelompokkan ke dalam empat kawasan bersejarah yaitu Kawasan Bandar Gresik, Kawasan Giri, Kawasan Bandar Jaratan dan Kawasan Bawean.
\end{abstract}

Kata Kunci : Perkembangan, Kota, Bandar, Gresik, Diakronik

\section{ABSTRACT}

Gresik Regency as a Bandar has been known since the Majapahit Empire because of its strategic location and high trading activities that have made Gresik a Bandar City. The existence of Bandar Gresik is one of the reasons for the diversity of history and culture contained in it because of the acculturation of the immigrant culture caused by the Bandar itself. Bandar is one of the triggers for community and economic development which is increasingly seen in the morphology of the City of Gresik Regency. The existence of various historical relics, both tangible and intangible, describes historical events that have occurred in Gresik Regency in the past and city developments that have occurred to the present. This historical event of Gresik Regency can then become its own identity and uniqueness for Gresik Regency. Therefore, it is necessary to conduct a study on the development of Gresik with the aim of seeing what the development of Gresik Regency looks like from year to year to find out the morphological form that existed at that time and how important it is for spatial regeneration in the future. This study uses a content analysis (CA) analysis approach and Diankronik analysis. The results of this study found 5 stages of the main period consisting of the Majapahit Empire, the Islamic Development Period, the Colonial Period, the Japanese Occupation Period, and the Early Independence Period. Based on the development period, they are grouped into four historical areas, namely the Bandar Gresik area, the Giri area, the Bandar Jaratan area and the Bawean area.

Keywords: Development, City, Bandar, Gresik, Diacronic

Copyright $\odot 2021$ JPWK-UNDIP This open access article is distributed under a Creative Commons Attribution (CC-BY-NC-SA) 4.0 International license. 
Sinaga, Tucunan, Satiawan, dan Rahmawati/ Jurnal Pembangunan Wilayah dan Kota, Vol. 17, No. 3, 2021, 266-275

Doi: $10.14710 / p w k . v 17 i 3.34417$

\section{PENDAHULUAN}

Terdapat beberapa kriteria sebuah kawasan dianggap sebagai pusaka (O'Donnell and Turner 2012). Berdasarkan kriteria ini, Kabupaten Gresik telah memenuhi hampir keseluruhan dari kriteria tersebut dengan adanya peninggalan sejarah dan budaya berupa bukti adanya peradaban mulai dari kehidupan kerajaan hingga kepercayaan dan sosial masyarakat yang masih ada hingga saat ini (Aysegul 2016). Kabupaten Gresik memiliki berbagai potensi daya tarik seperti wisata alam, peninggalan sejarah, wisata seni budaya dan terutama wisata cagar budaya diantaranya 8 lokasi wisata berupa situs makam, selain itu terdapat Kampung Kemasan yang merupakan potensi heritage skala internasional (Irastari and Suprihardjo 2012). Dengan situs heritage yang meliputi masjid dan makam Kabupaten Gresik memiliki potensi sebagai Kawasan heritage UNESCO telah memenuhi kriteria sebagai peninggalan dari sejarah perkembangan agama Islam di Indonesia yang ditandai keberadaan Makam Siti Fatimah binti Maimun (Rahmawati et al. 2016). Selain peninggalan sejarah berupa cagar budaya, Kabupaten Gresik juga memiliki berbagai budaya dan kebiasaan masyarakat yang menjadi kekhasan dan identitas lokal setempat yang sangat erat kaitannya dengan budaya islam yang berkembang di Kabupaten Gresik. Yang menarik dari berbagai tradisi ini selain karena hubungan yang erat dengan tradisi atau budaya dan hari besar dalam kepercayaan agama Islam, namun juga budaya yang berkembang di Kabupaten Gresik ini dipelopori dan dijalankan oleh masyarakat Kabupaten Gresik sendiri sebagai pelaku utama. Masyarakat dalam hal ini memegang peran tokoh utama dalam pelestarian budaya Kabupaten Gresik (BPS Gresik Regency 2013). Namun, pada kondisi eksistingnya saat ini pengunjung yang didominasi peziarah hanya berfokus pada kegiatan ziarah makam dan tokoh sejarah itu sendiri beserta perannya tapi kurang memahami nilai-nilai yang dimiliki oleh situs secara keseluruhan di Kabupaten Gresik (Gresik, n.d.)(Jokiletho 2008).

Morfologi sebagai suatu pendekatan berkaitan langsung dengan ekspresi ruang kota, yang diamati dari penampilan kota secara fisik (Hendro, Sejarah, and Diponegoro, n.d.). Dalam perkembangan morfologi kota di Kabupaten Gresik konsep Historical urban landscape (HUL) memiliki peran yang sangat penting karena konsep ini mengutamakan perkembangan kota terkait untuk kemudian menjadi identitas kota sehingga dalam perkembangan kota tersebut akan selalu didasarkan pada identitas dan kekhasan dari dalam hal ini Kabupaten Gresik sendiri. Oleh karena itu, sejarah dan urutan perkebangan Kabupaten Gresik sangat penting karena menjadi dasar dari konsep HUL itu sendiri. Ekspresi keruangan kota dapat digolongkan manjadi empat macam kenampakan utama dan enam kenampakan kombinasi, hal ini sebagian terjadi melalui proses tertentu yang dipengaruhi oleh faktor fisik don nonfisik, faktor fisik berkaitan dengan keadaan topografi, geomorfologi, perairan, dan tanah, faktor nonfisik antara lain berkaitan dengan penduduk kota, yaitu jumlahnya, kegiatannya (politik, ekonomi, sosial, budaya, dan teknologi), tingkat urbanisasi, perencanann tata ruang, zoning dan peraturan pemerintah. Selain itu, sirkulasi sarana transportasi, pusat pertumbuhan dengan fungsi khusus (industri dan perumahan) mempunyai peranan yang besar pula dalam mambentuk variasi ekspresi keruangan kenampakan kota (UNESCO 2013).

Pada konteks HUL pembangunan dan konservasi bangunan heritage didasarkan pada preservasi nilai. Konsep HUL yang merupakan pendekatan pelestarian heritage kota yang melihat pada konteks kawasan, berfokus pada seluruh lingkungan manusia dengan semua kualitas benda dan tak bendanya. Pendekatan ini berusaha untuk meningkatkan keberlanjutan perencanaan dan intervensi desain dengan memperhatikan lingkungan terbangun yang ada, warisan budaya tak benda, keragaman budaya, faktor sosial-ekonomi, dan lingkungan kebersamaan dengan nilai-nilai masyarakat setempat dan menjembatani keterlibatan komunitas, masyarakat dan swasta serta dukungan pemerintah dalam usaha konservasi dan pengembangan (O’Donnell and Turner 2012)(UNESCO 2016).

HUL sebagai sebuah definisi, memperluas pemahaman tentang kawasan helritage, mengidentifikasi elemen-elemen yang membuat keragaman kota dan menciptakan rasa tempat serta identitas kota. Lapisan-lapisan ini merupakan kekayaan yang perlu diakui dan ditingkatkan dalam strategi konservasi dan pembangunan kota. Pemahaman keberagaman budaya dan identitas dalam suatu kota akan memberikan 
pandangan dan pengetahuan yang baru dalam proses manajemen dan pembuatan keputusan dalam perencanaan kota. Stadia perkembangan kota akan menggambarkan identitas dan meletakkan Kabupaten Gresik khususnya kawasan Kota Lama di depan dan di tengah perencanaan yang berkelanjutan dengan mempertahankan identitas kawasan yang ditandai dengan bangunan dan benda peninggalan sejarah serta lingkungan terbangun yang ada, warisan budaya tak benda, keragaman budaya, faktor sosial-ekonomi, dan memperhatikan lingkungan kebersamaan dengan nilai-nilai masyarakat setempat (UNESCO 2016)(UNESCO 2013)(Amat 2018).

Berdasarkan kedua konsep sebelumnya, perlu adanya identifikasi nilai dan morfologi suatu ruang masa lalu khususnya pada Kota Bandar Gresik. Hal ini dilakukan untuk mengenali dan memahami bagaimana perkembangan kota serta kebudayaan pada Kota Bandar Gresik. Karena peristiwa yang terjadi di masa lalu merupakan ungkapan ilmu sosial yang telah berkembang serta dapat menjadi ilmu yang bermanfaat bagi pengembangan dan perkembangan manusia dimasa yang akan datang (Whitehand and Gu 2010). Sehingga masyarakat tidak hanya berfokus pada kegiatan ziarah tokoh sejarah yang ada di Kabupaten Gresik saja melainkan dapat mengenal bagaimana nilai kultural dan historis pada Kota Bandar Gresik. Studi ini bertujuan untuk melihat seperti apa perkembangan dari tahun ke tahun Kabupaten Gresik dengan kepentingan untuk mengetahui bentuk morfologi yang ada pada saat itu dan bagaimana pentingnya untuk regenarasi ruang di masa mendatang. Dalam hal ini penelitian terkait perkembangan morfologi Kabupaten Gresik sangat penting sebagai dasar penelitian untuk pengembangan Kota lainnya khususnya denga konsep pengembangan Historic Urban Landscape, sedangkan sejauh ini belum ditemukan penelitian terkait Kabupaten Gresik yang berbasis perkembagan morfologi.

\section{DATA DAN METODE}

Penelitian ini merupakan penelitian yang bersifat kualitatif yaitu dengan membuat gambaran serta menggali data melalui beberapa sumber untuk mengetahui Perkembangan Kabupaten Gresik di Masa Gresik Kota Bandar. Sedangkan pendekatan yang digunakan adalah pendekatan naturalisitk dengan kerangka yang menitikberatkan pada historical morphology dengan analisis diakronik (Kropf 2017; Noizet 2009; Whitehand and Gu 2010) dalam mengetahui perkembangan morfologi kota di Kabupaten Gresik. Studi mengenai konfigurasi ruang di masa lampau sering didekati dengan pendekatan morfologi, salah satu pendekatan yang relevan adalah pendekatan sejarah atau dikenal dengan historical morphology (Bianca, 2014; Kubat, 2010; Whitehand \& Gu, 2010). Penelitian ini dilakukan untuk membentuk sebuah kerangka mengenai apa yang terjadi di masa lalu sehingga dapat digunakan di masa mendatang sebagai bentuk guideline dalam perencanaan yang saat ini juga sedang digunakan UNESCO dalam konsep HUL.

\subsection{Teknik Pengumpulan Data}

Data-data penelitian ini didapat dengan melakukan studi pustaka, in depth interview dan focus group discussion (FGD) dengan expert terpilih melalui purposive sampling sebagai salah satu metode pengumpulan data secara kualitatif terutama pada penelitian terkait dengan kesejarahaan/ heritage (Paramita, Kristiana, and Lusi 2013; Tucunan, Sulistyandari, and Perkasa 2018). Patton, menjelaskan bahwa Teknik pemilihan sample secara purposive terdiri atas 13 jenis sampling dan salah satu jenis sampling adalah criterion sampling hal ini dilakukan untuk meningkatkan kredibilitas dan validitas dari penelitian kualitatif (Patton 1999; 2002). Wawancara dilakukan pada expert yang memiliki pengetahuan mengenai perkembangan Kabupaten atau peristiwa sejarah di Gresik, sehingga Perkembangan Kabupaten Gresik di Masa Gresik Kota Bandar dapat sesuai.

\subsection{Variabel Penelitian}

Sintesa pustaka dilakukan terlebih dahulu untuk memperoleh indikator dan variable penelitian yang digunakan dalam penelitian ini. Variabel penelitian yang digunakan untuk mengklasifikasikan Peninggalan Sejarah Kabupaten Gresik dapat dilihat pada tabel 1. 
Sinaga, Tucunan, Satiawan, dan Rahmawati/ Jurnal Pembangunan Wilayah dan Kota, Vol. 17, No. 3, 2021, 266-275

Doi: 10.14710/pwk.v17i3.34417

Tabel 1. Indikator dan Variabel Penelitian

\begin{tabular}{|c|c|c|}
\hline Indikator & Variabel & $\begin{array}{c}\text { Definisi } \\
\text { Operasional }\end{array}$ \\
\hline \multirow[t]{3}{*}{ Periode } & & $\begin{array}{l}\text { Periodesasi untuk pembagian unit } \\
\text { analisis pada Kabupaten Gresik. } \\
\text { Pembagian periodisasi dibuat } \\
\text { khusus sesuai dengan } \\
\text { perkembangan wilayah }\end{array}$ \\
\hline & Nama & Penamaan wilayah pada saat itu \\
\hline & $\begin{array}{l}\text { Bentuk Pemerintahan dan ciri } \\
\text { Kota }\end{array}$ & $\begin{array}{l}\text { Bentuk pemerintahan dan politik } \\
\text { yang ada pada saat periode } \\
\text { tersebut }\end{array}$ \\
\hline \multirow[t]{4}{*}{ Aktivitas Manusia } & Administratif & $\begin{array}{l}\text { Sistem administrasi yang berlaku } \\
\text { pada periode tersebut }\end{array}$ \\
\hline & Pusat Kota & Lokasi pada pusat kota \\
\hline & Karakteristik Masyarakat & $\begin{array}{l}\text { Karakteristik sosial dan ekonomi } \\
\text { masyarakat }\end{array}$ \\
\hline & Artefak & $\begin{array}{l}\text { benda yang dapat dipindahkan apa } \\
\text { pun yang dibuat atau dimodifikasi } \\
\text { oleh manusia setidaknya berusia } 50 \\
\text { tahun }\end{array}$ \\
\hline \multirow[t]{2}{*}{ Historical Built Environment } & Fitur & $\begin{array}{l}\text { benda yang tidak dapat diangkut } \\
\text { atau dipindahkan yang dibuat, } \\
\text { dimodifikasi manusia setidaknya } \\
\text { berusia } 50 \text { tahun }\end{array}$ \\
\hline & Situs & lokasi temuan arkeologis \\
\hline
\end{tabular}

\subsection{Teknik Analisis Data}

Pengolahan data dalam penilitian ini menggunakan teknik konten analisis. Teknik konten analisis dipilih untuk menyusun kesimpulan dengan melihat hasil in depth interview dan focus group discussion (FGD) yang berisi pendapat expert terkait Perkembangan Kabupaten Gresik di masa Gresik Kota Bandar berdasarkan studi pustaka. Proses diawali dengan menyusun kerangka stadia perkembangan Kabupaten Gresik dengan studi literatur yang dilanjutkan dengan triangulasi melalui in depth interview dan focus group discussion (FGD) dengan expert. Kemudian dilakukan analisis diakronik untuk mengetahui perkembangan morfologi kota di Kabupaten Gresik khususnya Perkembangan Kabupaten Gresik di Masa Gresik Kota Bandar.

\section{HASIL DAN PEMBAHASAN}

Seperti yang diuraikan pada gambar 1 stadia perkembangan Kabupaten Gresik terdiri dari 5 tahapan perkembangan dengan variable yang mewakili perkembangan morfologi kota diantaranya nama, ciri kota, pusat kota, artefak, kehidupan masyarakat dan kondisi lingkungan. Pada perkembangan perubahan nama menjadi Kabupaten Gresik seperti sekarang, terdadapat perubahan yang besar pada awal perkembangan terutama karena banyaknya pendatang dari luar negeri yang memberi julukan tertentu untuk Gresik dengan kaitannya pula dengan pengaruh Giri. Pada ciri kota, didominasi dengan kota perdagangan karena didasarkan fakta bahwa Gresik pada awal perkembangan merupakan Kota Bandar yang cukup terkenal, dan oleh karena itu pula pusat kota umumnya pada sekitar Bandar dan terdapat komunitas. Pada kondisi masyarakat dan lingkungan umumnya terbatas pada ciri kehidupan kota Bandar dan dagang dengan kegiatan ekonomi yang tinggi. Hal ini juga sejalan dengan seni yang berkembang dibuktikan dengan 
Sinaga, Tucunan, Satiawan, dan Rahmawati/ Jurnal Pembangunan Wilayah dan Kota, Vol. 17, No. 3, 2021, 266-275 Doi: $10.14710 /$ pwk.v17i3.34417

artefak yang ditemukan di Kabupaten Gresik (Prameswari and Kasdi 2013; Gandis Prameswari, Pendidikan Sejarah, and Ilmu Sosial 2013).

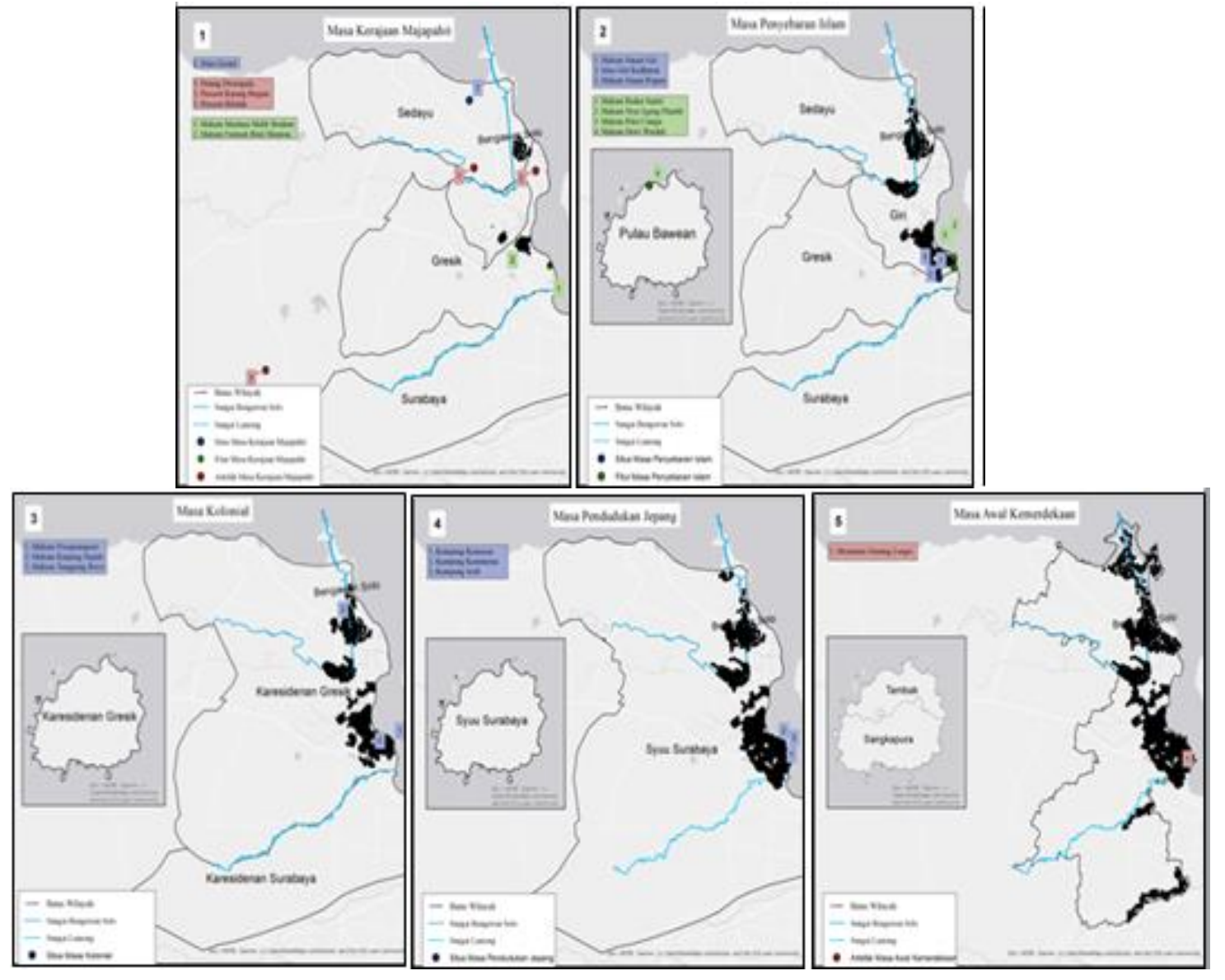

Sumber: Dilengkapi dan diadaptasi dari (Sinaga and Tucunan 2019b)

Gambar 1. Stadia Perkembangan Kabupaten Gresik

Periode Kerajaan Majapahit Hingga Masa Kemerdekaan

\section{Stadia 1 : Kerajaan Majapahit (abad 10-13)}

Masa kerajaan majapahit dimulai diperkirakan sebelum abad 10 hingga abad 13. Perkembangan pada awal di Masa Kerajaan Majapahit dimulai dengan penduduk Kerajaan yang sebagian bermukim di daerah yang dekat pelabuhan atau Bandar yang cukup terkenal pada saitu yaitu Bandar Gresik dan Bandar Jaratan yang terletak di aliran Sungai Bengawan Solo dan Sungai Lamong. Sedayu saat itu masih merupakan daerah sendiri, berbeda dengan Gresik, selain itu Gresik pun sebagian pada bagian selatan masih dimiliki oleh Surabaya, sementara belum ada keterangan mengenai Pulau Bawean pada masa Majapahit.

Gresik sebagai Bandar telah terkenal namanya sejak Masa Kerajaan Majapahit karena merupakan salah satu pintu Kerajaan Majapahit terbukti dari adanya peninggalan sejarah yang ditemukan yaitu prasati Karang Bogem dan Arca Dwarapala. Selain itu Gresik juga menjadi salah satu kekuatan Kerajaan Majapahit karena potensinya pada Bandar Perdagangan yang terkenal dan memiliki lokasi yang strategis, sehingga kehidupan masyarakat juga telah terpusat di kawasan Bandar. Pada abad 13 terdapat sumber yang mengatakan gresik disebut Qarr-syaik oleh pendatang Arab yang berarti tancapkan sesuatu.

Perkembangan stadia ini telah dimulai pada masa Sriwijaya, namun BCB yang masih ada pada masa Majapahit. pada masa ini selain berkembang Periode Hindu-Budha juga ditengarai mulai masuk penyebaran agama islam. Beberapa peninggalan sejarah pada masa ini diantaranya Patung Dwarapala, Prasasti Karang 
Sinaga, Tucunan, Satiawan, dan Rahmawati/ Jurnal Pembangunan Wilayah dan Kota, Vol. 17, No. 3, 2021, 266-275

Doi: $10.14710 / p w k . v 17 i 3.34417$

Bogem, Prasasti Biluluk, Situs Gosari dan makam Tokoh Syah Bandar Islam Maulana Malik Ibrahim (Gresik, n.d.)(Sinaga and Tucunan 2019a).

\section{Stadia 2: Masa Penyebaran Islam (abad 14-16)}

Masa penyebaran Islam dimulai kurang lebih pada abad 14 hingga abad 16. Kemudian pada masa penyebaran Islam kekuasaan Giri mulai terlihat dan perkembangan Islam semakin kuat sehingga Giri mulai berkembang sendiri berbeda dengan Gresik yang sangat terkenal dengan Bandar atau pelabuhan transit internasional tersebut. Terjadi beberapa perbedaan nama pada Gresik diantaranya Gerwarase seperti disebut Wisselibus dalam bukunya, Tse Tsun, Tsin Tsun oleh pendatang Cina pada tahun 1513 M, Agace oleh pendatang Portugis, Juga Qarra Sayik oleh pendatang Arab. Pada masa ini juga penduduk mulai menyebar sebagian besar pada Giri karena gerakan sosial pengaruh keagamaan (Islam) yang kuat. Giri dan Gresik pada saat itu menguasai karena pengaruh Islam dan dagang yang kuat, sementara Sedayu dan Bawean diketahui memiliki pemerintahannya sendiri.

Kemudian karena banyaknya pendatang sebagai pengaruh Bandar yang terkenal, Gresik memiliki banyak pendatang dengan berbagai suku dan RAS yang kemudian untuk memudahkan pemerintahan, oleh Belanda pada masa Kolonial dibuat bermukim secara berkelompok berdasarkan asal usul tersebut sehingga tercipta perkampungan masyarakat. Perkembangan Bandar sebagai pusat perdagangan dan perkembangan penyebaran Islam yang telah juga membentuk pusat kekuasaan tersendiri memberi keunikan tersendiri dalam perkembangan morfologi Kabupaten Gresik karena adanya elaborasi bandar, religi dan budaya pendatang yang tergambar pada peninggalan sejarah dari masa penyebaran islam nusantara. Beberapa peninggalan sejarah pada masa perkembangan Islam diantaranya didominasi oleh Makam Tokoh penyebar agama Islam dan sisa kerajaan atau kepemimpinan yang didasarkan oleh Penyebaran agama islam di nusantara.

\section{Stadia 3: Periode Kolonial (abad 17-19)}

Periode kolonial dimulai sekitar abada 17 hingga abad 19. Pada masa itu terdapat beberapa perubahan pada Nama Gresik diantaranya Giri-gisik, Giri-sik seperti disebut oleh Thimas Raffles, juga Giri-isa seperti disebut pada Serat Centini. Pada masa Kolonial pula Sedayu dan Bawen menjadi satu Karesidenan Besar dengan Gresik. Pada masa ini kegiatan Perdagangan khususnya di Bandar Gresik sangat tinggi karena didukung pembangunan yang dilakukan oleh Pemerintah Kolonial, selain pembangunan Bandar sebagai pusat perdagangan, pembangunan juga dilakukan sebagai usaha pertahanan oleh pemerintah Kolonial yang ditandaia dengan peninggalan berupa runtuhan Benteng Lodewijk di Mengare.

Kemudian salah satu pembanguna yang juga menjadi salah satu peninggalan terbesar, Gresik dilalui oleh jalur Pos Daendels. Pendatang dari Eropa sangat tinggi dan memunculkan akulturasi Budaya yang unik dengan budaya dari pendatang lain juga budaya lokal, termasuk perdagangan yang kemudian memicu persaingan dengan pelaku perdagangan lokal, juga pergerakan nusantara. Selain itu, masa kolonial juga membawa pengaruh morfologi yang besar pada Kabupaten Gresik khususnya pada bentuk bangunan yang ada, juga sistem pengelompokkan permukiman penduduk dan adanya pembangunan oleh Belanda yang melalui Kabupaten Gresik seperti pembangunan irigasi dan pemerintahan juga permukiman lokal melalui pengelompokkan permukiman masyarkat berdasarkan latar belakang yang sama. Beberapa peninggalan lainnya diantaranya makam beberapa tokoh pemerintah lokal yaitu Makam Bupati Poesponegoro, Tanggung Boyo dan Kanjeng Sepuh.

\section{Stadia 4: Periode Jepang (Tahun 1934-1953)}

Selanjutnya pada masa pendudukan Jepang, masa ini berkisar antara tahun 1934 hingga 1953. Permukiman penduduk semakin diperkuat keberadaan dan identitasnya oleh Jepang namun dengan sistem yang berbeda, Gresik termasuk di dalamnya Sedayu dan Bawean menjadi satu di bawah kepemimpinan Surabaya menjadi Syuu Surabaya. 
Pemerintahan terpusat di Surabaya. Hingga masa ini, Gresik masih sangat dikenal dengan Bandar, meskipun telah melalui penutupan sungai yang menyebabkan berkurangnya Bandar perdagangan lokal namun tidak mengurangi perdagangan di Bandar Gresik yang juga semakin didukung dengan meningkatnya jumlah penduduk Gresik yang memiliki usaha yang sukses seperti usaha kulit dan lain-lain sehingga kegiatan perdagangan dan ekonomi di Kabupaten Gresik sangat tinggi. Pada masa ini budaya Jepang mengharuskan penghapusan beberapa sistem Kolonial yang tersisa sehingga terjadi beberapa perubahan khususnya pada pemerintahan dan permukiman penduduk. Selain itu juga pada masa ini pusat kegiatan mulai bergeser karena mulainya Industrialisasi di Kabupaten Gresik yang ditandai dengan pembangunan Pabrik Semen Gresik di bagian selatan Gresik.

\section{Stadia 5: Periode Awal Kemerdekaan (Tahun 1945)}

Periode awal kemerdekaan dimulai saat menuju kemerdekaan Indonesia, proklamasi kemerdekaan hingga beberapa saat sesudahnya yaitu dimulai tahun 1945. Hingga akhirnya pada akhirnya Gresik menjadi satu kabupaten sendiri dengan Sedayu dan Pulau Bawen dengan beberapa bagian Surabaya bagian barat yang saat ini menjadi kawasan Industri pada masa awal kemerdekaaan.

Pemerintahan pada Masa ini telah terpusat pada Gresik sebagai pusat kabupaten. Pada Masa ini, kegiatan masyarakat sebagian besar terfokus pada pergerakan sebagai pemulihan dari penjajahan. Selain itu kegiatan industri mulai berkembang dan mengalami kemajuan yang ditandai dengan bertambahnya jumlah industri di Kabupaten Gresik dan pertumbuhan permukiman masyarakat dan fasilitas umum di sekitar kawasan Industri. Salah satu peninggalan sejarah yang terkenal pada periode ini adalah bukti pergerakan masyarakat Gresik yaitu Monumen Gunung Lengis.

Berdasarkan hasil yang telah dijabarkan pada penjelasan sebelumnya, perkembangan Kabupaten Gresik melalui berbagai perubahan yang diantaranya dipengaruhi oleh adanya pelabuhan perdagangan yang menyebabkan banyaknya pendatang dari berbagai daerah di Gresik oleh karena itu perkembangan Gresik dapat disimpulkan dalam lima zaman besar yang dapat menjadi titik ukur utama (Mustakim 2010). Pada masa kerajaan Majapahit, Gresik merupakan bagian dari kekuasaan kerajaan tersebut. Hal ini dibuktikan dengan ditemukannya sebuah prasasti di sebuah dinding goa di Desa Gosari, Ujungpangkah, Gresik. Prasasti beraksara Jawa kuno ini ditulis pada tahun 1298 Saka atau tahun 1376. Berdasarkan angka tahun tersebut maka prasasti kemungkinan besar adalah peninggalan Kerajaan Majapahit (Mustakim 2017). Gresik sebagai bandar dagang selalu mengalami perubahan. Pada awal abad ke-15 terdapat dua bandar dagang yaitu Bandar Dagang Jaratan dan Bandar Dagang Gresik. Dua pelabuhan kembar ini terletak berhadapan di muara sungai. Diperkirakan bahwa Pelabuhan Gresik pada masa itu terletak di Desa Karang Kiring sekarang yang berhadapan dengan Sungai Lamong, sedangkan Pelabuhan Jaratan terletak di Desa Mengare, berhadapan dengan Sungai Bengawan Solo Lawas. Sejak zaman Majapahit, Bandar Dagang Gresik sudah ramai dikunjungi para pedagang, baik dari Nusantara maupun mancanegara (Mustakim 2005). Sidayu-Gresik dalam Bayang-bayang Mataram dan VOC (1626-1717 M) Sidayu pada saat ini merupakan kota kecamatan di bawah pemerintah Kabupaten Gresik. Sebelum menjadi bagian dari Kabupaten Gresik Sidayu ternyata memiliki sejarahnya sendiri. Dimana Sidayu pernah memiliki pengaruh yang sangat besar dalam percaturan politik Mataram kira-kira sejak abad ke-16 M. Meilink Roelofsz dalam bukunya tentang perdagangan di Asia dan pengaruh Eropa di kepulauan nusantara antara tahun 1500-1630 menyebutkan bahwa diduga Sidayu telah ada sejak masa peralihan dari masa klasik ke masa Islam sebagai sebuah daerah agraris feodal, terletak diantara Tuban dan Gresik (Mustakim 2010). Pada masa pendudukan Jepang di Indonesia, susunan pemerintahannya sebagian besar masih mengikuti susunan pemerintahan Hindia Belanda, hanya pembagian administrasi menurut propinsi (Gewest) dihapuskan. Sejak tanggal 8 Agustus 1942 pulau Jawa dibagi dalam 17 Syuu (semacam Residentie sedangkan di bekas propinsi Jawa Timur pada waktu itu muncul syuu-syuu, antara lain Surabaya, Bojonegoro, Madiun, Kediri Malang, Besuki, dan Madura. Setiap Syuu dipimpin oleh seorang Syuucokan yang kedudukannya sama dengan seorang Gubernur (Kasdi 2017). Selain didominasi oleh peristiwa pergerakan nasional dan usaha kemerdekaan, Dari hasil survei disusun laporan berjudul "Result of Investigatoon by Core Drilling of The Pliocebe Limestone Near 
Gresik" pada Januari 1951. Dalam laporan tersebut dijelaskan bahwa: dari bagian deposit yang disurvei itu saja telah menunjukkan adanya lapisan bahan galian yang dapat mencukupi persediaan untuk produksi sebuah pabrik semen selama 60 tahun dengan kapasitas produksi rata-rata 250.000 ton per tahun. Sebagai realisasi, pelaksanaan pembangunan pabrik semen Gresik tersebut oleh Pemerintah diserahkan kepada BIN (Bank Industri Negara). Selanjutnya dengan penugasan tersebut BIN mulai mengadakan persiapanpersiapan. Dalam hal ini BIN menyediakan pembiayaan lokal berupa rupiah sedang untuk pembiayaan valuta asing digunakan kredit dari Eximbank (Amerika Serikat). Pada tanggal 25 Maret 1953, dengan Akte Notaris Raden Meester Soewandi No. 41 di Jakarta, didirikanlah badan hukum N.V. Pabrik Semen Gresik, dengan Presiden Komisaris-nya: Bank Industri Negara, dan Direkturnya yang pertama Ir Ibrahim bin Pangeran Mohammad Zahier, pegawai tinggi Kementerian Perekonomian (Widodo and dkk 2004).

Berdasarkan uraian penelitian yang dijelaskan pada paragraf sebelumnya dapat disimpulkan bahwa perkembangan morfologi Kabupaten Gresik walaupun batasan waktu diantaranya tidak dapat ditentukan dengan jelas dan rigid namun dapat dibagi ke dalam 5 periode utama, setiap periode semuanya dipengaruhi oleh Gresik sebagai Kota Bandar dan memiliki ciri khas morfologi masing-masing termasuk diantaranya pada ciri dan bentuk kota serta pemerintahan, juga kehidupan masyarakat.

\section{KESIMPULAN}

Dari hasil penelitian perkembangan Kabupaten Gresik di masa Kota Bandar Gresik, ditemukan konsensus expert bahwa Kota Bandar Gresik merupakan salah satu tahapan Kabupaten Gresik yang paling terkenal yang terjadi cukup paling lama karena terdiri dari beberapa periode dalam stadia perkembangan Kabupaten Gresik. Kota Bandar Gresik menjadi salah satu yang paling lama tidak terlepas dari keberadaan Bandar sendiri yang saat itu merupakan Bandar perdagangan yang sangat besar dan terkenal baik di Nusantara maupun mancanegara karena lokasi nya yang strategis. Selain itu, pada masa ini juga terdapat perkembangan masyarakat baik secara ekonomi maupun sosial karena adanya perkebangan agama islam yang termasuk di dalamnya. Kemudian, dari Kota Bandar Gresik juga menghasilkan peninggalan sejarah terbesar dan terbanyak yang perlu dilestarikan karena mengandung nilai tertentu berupa akulturasi budaya yang unik dan khas Kabupaten Gresik. Hal ini tidak terlepas dari akulturasi budaya pendatang karena adanya bandar dan memiliki peran dalam kondisi masyarakat dan lingkungan serta perkembangan kota dan menjadi identitas pada bentuk Kabupaten Gresik di masa sekarang ini.

\section{PERNYATAAN RESMI}

Ucapan syukur dan terima kasih penulis ucapkan kepada DRPM dan PDPM ITS atas kesempatan juga dukungan dana yang diberikan untuk menyelenggarakan dan menyelesaikan penelitian ini hingga akhir, serta kepada pihak Pemerintah Kabupaten Gresik untuk kerja samanya dalam penyusunan penelitian ini.

\section{REFERENSI}

Amat, Rohayah Che. 2018. "Inheriting the City: Historic Urban Landscape of George Town UNESCO World Heritage Site.” Planning Malaysia. https://doi.org/10.21837/pmjournal.v16.i5.424.

Aysegul, Kaya Tanriverdi. 2016. "Method for Assessment of the Historical Urban Landscape." In Procedia Engineering. https://doi.org/10.1016/j.proeng.2016.08.648.

BPS Gresik Regency. 2013. “Gresik,” 1-10.

Gandis Prameswari, Ayu, Jurusan Pendidikan Sejarah, and Fakultas IImu Sosial. 2013. "PELABUHAN GRESIK PADA ABAD XIV Aminuddin Kasdi." Journal Pendidikan Sejarah.

Gresik, Dinas Pariwisata dan Kebudayaan. n.d. "Daftar Cagar Budaya Gresik." Hendro, Eko Punto, Jurusan Sejarah, and Universitas Diponegoro. n.d. "2861-6253-1-Sm."

Irastari, Volare Amanda, and Rimadewi Suprihardjo. 2012. "Pelestarian Kawasan Cagar Budaya Berbasis Partisipasi Masyarakat ( Studi Kasus : Kawasan Cagar Budaya Bubutan, Surabaya )." Jurnal Teknik ITS 1 (1): 63-67. Jokiletho, Jukka. 2008. The World Heriatge List: What Is OUV? Defining the Outstanding Universal Value of Cultural 
Sinaga, Tucunan, Satiawan, dan Rahmawati/ Jurnal Pembangunan Wilayah dan Kota, Vol. 17, No. 3, 2021, 266-275

Doi: $10.14710 /$ pwk.v17i3.34417

World Heritage Properties. Monuments and Sites Edited by ICOMOS.

Kasdi, Aminuddin. 2017. Perkembangan Kota Gresik. UNESA University Press.

Kropf, Karl. 2017. The Handbook Of Urban Morphology. The Handbook Of Urban Morphology.

https://doi.org/10.1002/9781118747711.

Mustakim. 2005. Gresik Sejarah Bandar Dagang Dan Jejak Awal Islam Tinjauan Historis Abad XIII - XVII. Citraunggul

Laksana.

- 2010. Gresik Dalam Lintasan Lima Zaman. Pustaka Eureka.

- 2017. Satu Kota Tiga Zaman. Pustaka Media Guru.

Noizet, Hélène. 2009. "Fabrique Urbaine: A New Concept in Urban History and Morphology.” Urban Morphology.

O’Donnell, Patricia M., and Michael Turner. 2012. "The Historic Urban Landscape Recommendation: A New UNESCO

Tool for a Sustainable Future." In 49th World Congress of the International Federation of Landscape Architects, IFLA 2012.

Paramita, Astridya Kristiana, and Lusi. 2013. "TEKNIK FOCUS GROUP DISCUSSION DALAM PENELITIAN KUALITATIF

(Focus Group Discussion Tehnique in Qualitative Research)." Buletin Penelitian Sistem Kesehatan.

Patton, M. Q. 2002. "Qualitative Analysis and Interpretation.” In Qualitative Research \& Evaluation Methods.

Patton, M Q. 1999. "Enhancing the Quality and Credibility of Qualitative Analysis.” Health Services Research.

Prameswari, Ayu Gandis, and Aminuddin Kasdi. 2013. "PELABUHAN GRESIK PADA ABAD XIV Ayu Gandis Prameswari Aminuddin Kasdi." AVATARA, e-Journal Pendidikan Sejarah.

Rahmawati, Dian, Rimadewi Suprihardjo, Eko Budi Santoso, Rulli Pratiwi Setiawan, Karina Pradinie, and Mochamad Yusuf. 2016. "Penerapan Metode Rootcause Analysis (RCA) Dalam Pengembangan Kawasan Wisata Cagar Budaya Kampung Kemasan, Gresik.” Jurnal Penataan Ruang. https://doi.org/10.12962/j2716179x.v11i1.5211.

Sinaga, Gratia Ananda, and Karina Pradinie Tucunan. 2019a. "Klasifikasi Benda Arkeologi Kabupaten Gresik Dalam Tangible Intangible Heritage."

- 2019b. "Stadia Perkembangan Kabupaten Gresik."

Tucunan, Karina Pradine, Utari Sulistyandari, and M Ilham Perkasa. 2018. "ARTEFAK DALAM KONTEKS PERKEMBANGAN KAWASAN HERITAGE ISLAM.” Jurnal Planologi. https://doi.org/10.30659/jpsa.v15i2.3523.

UNESCO. 2013. "New Life for Historic Cities. The Historic Urban Landscape Approach." New Life for Historic Cities, 24. . 2016. "The HUL Guidebook." The HUL Guide, 59.

Whitehand, J. W.R., and Kai Gu. 2010. “Conserving Urban Landscape Heritage: A Geographical Approach.” In Procedia - Social and Behavioral Sciences. https://doi.org/10.1016/j.sbspro.2010.05.047.

Widodo, Dukut Imam, and dkk. 2004. Grissee Tempoe Doeloe. Pemerintah Kabupaten Gresik.

Amat, Rohayah Che. 2018. "Inheriting the City: Historic Urban Landscape of George Town UNESCO World Heritage Site.” Planning Malaysia. https://doi.org/10.21837/pmjournal.v16.i5.424.

Aysegul, Kaya Tanriverdi. 2016. "Method for Assessment of the Historical Urban Landscape." In Procedia Engineering. https://doi.org/10.1016/j.proeng.2016.08.648.

BPS Gresik Regency. 2013. "Gresik," 1-10.

Gandis Prameswari, Ayu, Jurusan Pendidikan Sejarah, and Fakultas Ilmu Sosial. 2013. "PELABUHAN GRESIK PADA ABAD XIV Aminuddin Kasdi." Journal Pendidikan Sejarah.

Gresik, Dinas Pariwisata dan Kebudayaan. n.d. "Daftar Cagar Budaya Gresik."

Hendro, Eko Punto, Jurusan Sejarah, and Universitas Diponegoro. n.d. "2861-6253-1-Sm.”

Irastari, Volare Amanda, and Rimadewi Suprihardjo. 2012. "Pelestarian Kawasan Cagar Budaya Berbasis Partisipasi Masyarakat ( Studi Kasus : Kawasan Cagar Budaya Bubutan, Surabaya ).” Jurnal Teknik ITS 1 (1): 63-67.

Jokiletho, Jukka. 2008. The World Heriatge List: What Is OUV? Defining the Outstanding Universal Value of Cultural World Heritage Properties. Monuments and Sites Edited by ICOMOS.

Kasdi, Aminuddin. 2017. Perkembangan Kota Gresik. UNESA University Press.

Kropf, Karl. 2017. The Handbook Of Urban Morphology. The Handbook Of Urban Morphology. https://doi.org/10.1002/9781118747711.

Mustakim. 2005. Gresik Sejarah Bandar Dagang Dan Jejak Awal Islam Tinjauan Historis Abad XIII - XVII. Citraunggul Laksana.

- 2010. Gresik Dalam Lintasan Lima Zaman. Pustaka Eureka. 2017. Satu Kota Tiga Zaman. Pustaka Media Guru.

Noizet, Hélène. 2009. "Fabrique Urbaine: A New Concept in Urban History and Morphology." Urban Morphology. O’Donnell, Patricia M., and Michael Turner. 2012. "The Historic Urban Landscape Recommendation: A New UNESCO Tool for a Sustainable Future." In 49th World Congress of the International Federation of Landscape Architects, 
IFLA 2012.

Paramita, Astridya Kristiana, and Lusi. 2013. "TEKNIK FOCUS GROUP DISCUSSION DALAM PENELITIAN KUALITATIF

(Focus Group Discussion Tehnique in Qualitative Research)." Buletin Penelitian Sistem Kesehatan.

Patton, M. Q. 2002. "Qualitative Analysis and Interpretation.” In Qualitative Research \& Evaluation Methods.

Patton, M Q. 1999. "Enhancing the Quality and Credibility of Qualitative Analysis." Health Services Research.

Prameswari, Ayu Gandis, and Aminuddin Kasdi. 2013. "PELABUHAN GRESIK PADA ABAD XIV Ayu Gandis Prameswari Aminuddin Kasdi." AVATARA, e-Journal Pendidikan Sejarah.

Rahmawati, Dian, Rimadewi Suprihardjo, Eko Budi Santoso, Rulli Pratiwi Setiawan, Karina Pradinie, and Mochamad Yusuf. 2016. "Penerapan Metode Rootcause Analysis (RCA) Dalam Pengembangan Kawasan Wisata Cagar

Budaya Kampung Kemasan, Gresik.” Jurnal Penataan Ruang. https://doi.org/10.12962/j2716179x.v11i1.5211.

Sinaga, Gratia Ananda, and Karina Pradinie Tucunan. 2019a. "Klasifikasi Benda Arkeologi Kabupaten Gresik Dalam

Tangible Intangible Heritage."

- 2019b. "Stadia Perkembangan Kabupaten Gresik."

Tucunan, Karina Pradine, Utari Sulistyandari, and M Ilham Perkasa. 2018. "ARTEFAK DALAM KONTEKS

PERKEMBANGAN KAWASAN HERITAGE ISLAM.” Jurnal Planologi. https://doi.org/10.30659/jpsa.v15i2.3523.

UNESCO. 2013. "New Life for Historic Cities. The Historic Urban Landscape Approach.” New Life for Historic Cities, 24. . 2016. "The HUL Guidebook." The HUL Guide, 59.

Whitehand, J. W.R., and Kai Gu. 2010. "Conserving Urban Landscape Heritage: A Geographical Approach.” In Procedia - Social and Behavioral Sciences. https://doi.org/10.1016/j.sbspro.2010.05.047.

Widodo, Dukut Imam, and dkk. 2004. Grissee Tempoe Doeloe. Pemerintah Kabupaten Gresik. 